\title{
STATE POLICY OF SOCIAL SECURITY IN THE CONDITIONS OF DECENTRALIZATION OF POWER
}

\section{Iana Sergeeva ${ }^{1}$}

DOI: https://doi.org/10.30525/978-9934-26-050-6-38

Today, in the conditions of unstable economic, political and social situation in Ukraine, it is extremely necessary to carry out a reform in the field of social protection of the population of Ukraine, which provides for measures to organize and provide social services to internally displaced persons. are in difficult life circumstances and need outside help. In modern conditions there is a tendency to convergence of national social protection systems, which is manifested in the unification of their features and characteristics in terms of ensuring a balance between social goals and the market, development of social partnership and social inclusion, unification of social standards and development of social standards. services. However, the characteristics characteristic of each model of social protection of the population, generated by the interaction of factors (economic, political, socio-cultural, etc.), inherent in different economic systems. The modern paradigm of human development forms the latest conditions and principles of economic growth in terms of social inclusion of society. Theoretical principles of social protection, its principles, target motivation and objective necessity in the early stages of development of the capitalist economy were laid down in the works of the classics of economics. Conceptual approaches and a comprehensive analysis of the problems of socialization of the world economy and its mechanisms, diversification of social services and its tools, issues of social cohesion, implementation of policies to regulate social support of vulnerable groups, including on the basis of social security are most fully reflected in such works. scientists such as I. Kolupaeva [1], O. Soskin [2], V. Bodrov [3], J. Zhalilo [4], A. Hrytsenko [5], N. Grazhevska [6] and others. The state of the social protection system of Ukraine indicates the need for more detailed analysis and specific proposals to improve the existing system in the near future in terms of overcoming the social disintegration of social insecurity of certain categories of citizens and ensuring equal access to social services in an inclusive national economic system.

In the context of globalization of the world space, the state policy of each country in the field of social protection expands its format to the system of social services, transforming into an integral attribute of national economic

${ }^{1}$ Donbas State Engineering Academy, Ukraine 
systems, reflecting the level of their socialization. The processes of globalization of economic and political relations, causing rapid changes in geographical borders, national economic, social and cultural systems, and extrapolation of the Western model of socio-economic development to other traditional models inevitably lead to a change in approaches to social protection. One of them is to approach at least the standards, provide social guarantees for all working and disabled and extend them to these people, regardless of the country in which they are located. The realities of the current socio-economic development of Ukraine, generated by its gradual involvement in the processes of globalization, pose new challenges to the Ukrainian state in the field of social protection. The growing complexity of socio-economic processes and related challenges to the social protection of the population of Ukraine require the expansion of state functions in this area. Economic, technological, demographic, environmental and other factors are increasingly influencing the development of the Ukrainian economy and society as a whole, necessitate the development of an adequate long-term strategy and the implementation of sound social protection programs. According to the authors, it should include an effective system of state regulation of employment, which is an arena for the manifestation of human skills and abilities and where the preconditions are created for solving many problems in all spheres of life of our society. In determining the main ways to modernize the institution of employment should be based on the fact that the development of the economic system is based on the action of objective economic laws that determine the logic of economic processes and phenomena. According to this, social work as a source of social wealth and a condition of life of society should be used rationally, in the most appropriate form. The latter relies on employment, which appears as a function of social production and a form of correspondence between labor supply and demand. It follows that the use of human resources is one of the always pressing problems of state regulation of socio-economic development of society, is a strategic goal of functioning.

The strategy of integration of internally displaced persons and implementation of long-term decisions on internal displacement until 2020 is aimed at solving the problem of internal displacement of Ukrainian citizens and its consequences, including host territorial communities, creating effective public administration tools, meeting urgent and permanent needs of internally displaced persons. persons. Previous government strategies have focused on meeting the priority needs of internally displaced persons, with the aim of identifying long-term solutions to the problems of internally displaced persons. As a result, those who are currently internally displaced will no longer need specific assistance and protection measures in connection with 
their displacement and will be able to exercise their rights without restriction on an equal footing with other citizens.

The inconsistency of formal and informal institutions, their inconsistency, extractive nature lead to changes in the economic system, which inevitably causes a decline in confidence and its crisis. The growth of contradictions and the slowdown in economic development due to the socio-economic crisis reduce the possibility of transforming formal and informal institutions, thus creating a trap of inconsistency in the quality of economic development. Crises as a natural process of development of the economic system have a complex nature, which manifests itself as shocks of the socio-economic sphere of society.

In order to prevent existing threats, according to the author, the strategic line and the corresponding program of development of the national economic system should be coordinated with the system of government and society, formulated goals and scientific substantiation of methodology, methods and mechanisms for achieving these goals.

The strategic platform for building a stable, productive and financially viable domestic system of social protection is economic growth based on the concept of sustainable development with an organic combination of economic, social and environmental components. Conditions and factors for ensuring the implementation of this concept in Ukraine are reforming the institution of property, focusing the economy on the establishment of the sixth technological structure, stimulating scientific and technical activities in the public and corporate sectors, completing the national innovation system, creating a favorable investment climate in the country, increasing all components of socialization of the economy. A key component of the effective functioning of the social protection system for internally displaced persons is the modernization of the employment institution. Separating the concept of government action for overcoming the crisis in the country, taking into account regional problems of social protection will overcome the social disintegration of social insecurity of internally displaced persons in eastern Ukraine and ensure equal access to social services in an inclusive national economic system.

\section{References:}

1. Kolupaieva I., Shevchenko O. (2019) Justification of scenarios of state regulatory policy of Ukraine. Proceedings of the International conference of Innovation in Science and Education. March 20-22. Prague Czech Republic.

2. Soskin O. (2014). Narodnyj kapitalizm: ekonomichna modelj dlja Ukrajiny [Narodnyi kapitalizm: ekonomichna modely dlya Ukrainy]. Kyiv: IST Publishing House, 396 p. 
3. Bodrov V. (2002). Transformacija ekonomichnykh system: koncepciji, modeli, mekhanizmy reghuljuvannja ta upravlinnja [Transformation of economic systems: concepts, models, mechanisms of regulation and management]: textbook. way. $104 \mathrm{p}$.

4. Zhalilo J. (2016). Osoblyvosti realizaciji ekonomichnoji polityky derzhavy v umovakh suchasnykh tendencij suspiljnogho rozvytku [Peculiarities of realization of economic policy of the state in the conditions of modern tendencies of social development]. Economic theory, vol. 1, pp. 39-52.

5. Hrytsenko A. (2016). Rekonstruktyvnyj ekonomichnyj rozvytok, zmist, osnovni naprjamy i vektor socialjnoji spravedlyvosti [Reconstructive economic development, content, main directions and vector of social justice]. Economic theory, vol. 4, pp. 5-19.

6. Grazhevska N. (2014). Komparatyvnyj pidkhid do analizu ghlobaljnoji konkurentospromozhnosti nacionaljnykh ekonomik [Comparative approach to the analysis of global competitiveness of national economies]. Theoretical and applied issues of economics, vol. 1(28), pp. 15-24. 